\title{
Zneužití tématu bohatství komunistickým režimem na príkladu časopisu Charita
} Rudolf Svoboda

Na jaře roku 2013 se na Teologické fakultě Jihočeské univerzity v Českých Budějovicích konalo symposium s názvem Pastorace bohatých - Východiska, impulzy, problémy a možnosti řešení reflektované z hlediska biblického, historického, etického, psychologického a pastorálně teologického.' Toto setkání zcela jasně ukázalo, že témata bohatství, resp. bohatých a pastorace bohatých jsou pro současnou církev zejména v západním civilizačním okruhu velmi aktuální. Protože se jedná o témata $\checkmark$ odborných diskusích zatím relativně málo frekventovaná, rozhodli se účastníci symposia předložit své poznatky širší veřejnosti v odborných studiích. Tato studie je jednou z nich.

Následující text je rozdělen do dvou částí. První část chce ve stručnosti a obecněji poukázat na některá metodologická omezení, se kterými se badatelé v rámci zkoumání témat bohatství, bohatých nebo pastorace bohatých z církevně-historického hlediska mohou setkat. Je do značné míry dozvukem výše zmíněného symposia a zaměřuje se na ona východiska, impulzy, problémy a možnosti řešení. Otevírá tak prostor pro druhou část a obsahuje $v$ sobě mimo jiné i implicitní vysvětlení názvu této studie. Ve své druhé části se studie zabývá velmi konkrétní problematikou zneužití tématu bohatství v komunistické propagandě, jejǐž platformou se stal na počátku padesátých let časopis Charita.

\section{Metodologické úvahy aneb jak uchopit složité církevně-historické téma v kontextu teologické diskuse}

Uvažujeme-li o vztahu teologie a historie, dá se v současné době říci, že teologové obecně přijímají výsledky historického bádání a do značné míry z něho vycházejí. Historie, jejímž oborem je i církevní historie, má kromě jiného za úkol dodávat teologům věrohodné podklady a souvislosti pro jejich uvažování (samozřejmě tento vztah platí do jisté míry i obráceně). ${ }^{2}$ $S$ ohledem na čtenáře tohoto časopisu, jehož profil není povýtce církevně-historický, a také $\mathrm{v}$ důsledku diskusí na výše zmíněném symposiu vedených zejména s teology různých odborností, bych rád osvětlil, proč je téma bohatých či bohatství v dějinách, či dokonce pastorace bohatých $v$ dějinách, problematické pojmout přehledovým způsobem ve smyslu "od-do", a nabídl uchopení méně diskutabilní - o němž ostatně vypovídá již samotný název této studie. ${ }^{3}$ Z obecnějšího pohledu je možné říci, že chce-li badatel více proniknout do témat vinoucích

1 Toto symposium se konalo na Teologické fakultě Jihočeské univerzity v Českých Budějovicích 18. dubna 2013.

2 O místě církevních dějin v rámci historie a teologie, o jejích úkolech a metodách jsem již hovořil obecněji i konkrétněji v několika studiích. Viz Rudolf SVOBODA, Osvícenství, teologie a církevní historie, in: Cornova, Revue České společnosti pro výzkum 18. století a Filozofické fakulty Univerzity Karlovy v Praze, roč. 1, č. 1/2011, s. 11-26; Rudolf SVOBODA, Boublíkova teologie dějin spásy. Myšlenky česko-ř́mského teologa jako inspirace pro církevní historii, in: Kateřina BRICHCÍNOVÁ, Karel SKALICKÝ, František ŠTĖCH, Tomáš VEBER (eds.), Teologie v utkání s pluralitou náboženství. Př́nos Vladimíra Boublika v př́stupech a hodnoceních jeho žáků, Kostelní Vydři: Karmelitánské nakladatelství, 2009, s. 69-76; Rudolf SVOBODA, Theology and the Church History: Selected Questions towards their Mutual Relationship, in: Obnova činnosti košického kňažského seminára po roku 1989. Zborník prispevkov z medzinárodnej vedeckej konferencie Košice 6. októbra 2009, Prešov: Teologická fakulta KU v Ružomberoku - Vydavatelstvo Michala Vaška, 2009, s. 58-60

3 Právě na výše zmíněném symposiu jsem totiž byl konfrontován s očekáváním, že přednesu stručné a jasné stanovisko o tom, „,jak to v dějinách bylo". 
se např́íc dějinami křest'anství, nemůže mít za to, že když si vybere pohledy na tu kterou problematiku nejprve z biblických textů, pak z významných děl autorů raného křest'anství, z děl velkých učenců středověku, z výroků koncilů či papežů až do současnosti, bude tím dostatečně postižená historická část teologické problematiky. Chronologicky řadit jednotlivé nalezené "výroky“ či „údaje“ bez hlubšího historického kontextu dává smysl např. v Denzingerovi, pokud sledujeme výroky učitelského úřadu církve. ${ }^{4}$ Avšak pokud bychom chtěli takto pojednat o některém $z$ historických témat - kterým například pastorace bohatých v dějinách církve zcela jistě je (čímž neříkám, že to není i téma teologické) - dostali bychom zúžený pohled na problematiku, který by $\mathrm{k}$ hlubšímu poznání tématu přinesl velmi málo. Jinak řečeno takové přehledové studii by chybělo vědomí toho, jak hluboké odlišnosti existují v obdobích, staletích, místech, naukách a generacích lidí. Odlišnosti někdy tak hluboké, nesrovnatelné a vzájemně nesnadno propojitelné, že pokoušel-li by se někdo jednotlivé pohledy různých epoch či lidí spojit do jasné a přehledné linie, mohlo by dojít (a dochází) k pověstnému „míchání jablek s hruškami“. Ačkoli by se mohlo zdát, že společný jmenovatel daný teologickým tématem zcela dostačuje, existuje zásadní riziko vytváření takových dějin, které nikdy nebyly. Tím neříkám, že by se dějiny měly stát pouze doménou historiků, kteří znají veškeré souvislosti - což vlastně ani není možné -, ale upozorňuji na fakt, že historie má jako každá vědecká disciplína svá pravidla, postupy a metody, které je třeba dodržovat a respektovat.

Další neopominutelnou záležitostí je fakt, že historik musí ve svých zkoumáních vycházet nejen z primární a sekundární literatury, ale především z pramenů, které pečlivě a kriticky interpretuje - mimo jiné díky širokým znalostem té které doby, popřípadě autora, kontextu vzniku díla, atp. Podobně kriticky interpretovat je nutné i primární a sekundární literaturu. Dělat např. závěry $\mathrm{z}$ toho, co naleznu v sekundární literatuře, popřípadě "skládat" právě $\mathrm{z}$ toho, co je uvedeno $\mathrm{v}$ sekundární literatuře, jakési přehledné tematické linie - a dokonce $\mathrm{z}$ nich i něco vyvozovat (sic!) - opět téměř zaručeně povede ke zkreslení zpracovávaného tématu. ${ }^{5}$

Kritik by nyní mohl namítnout, že přece dostatečně erudovaný člověk by s vědomím zmíněných odlišností přehledové téma táhnoucí se dějinami církve mohl zpracovat opravdu poctivě a do hloubky. Možná mohl, ale ukazuje se, že se to zatím podařilo spíše zcela výjimečně. ${ }^{6}$ Chtěl bych v této věci odkázat na diskuse, jež jsou v obci českých církevních historiků a teologů vedeny

4 Mám na mysli kompendium Heinrich DENZINGER, Enchyridion symbolorum definitionum et declarationum de rebus fidei et morum. Kompendium der Glaubensbekenntnisse und kirchlichen Lehrentscheidungen. Lateinisch - Deutsch. Freiburg im Breisgau: Herder Verlag, 1991.

5 Uvedu nyní jeden příklad nedávného ne zcela št́astného postupu z českého prostředí. Praktický teolog Jakub Doležel, působící na Cyrilometodějské teologické fakultě, nedávno obhájil disertační práci Teoretické ukotvení církevní sociální práce na pozadí obecných a českých charitních dějin až po encykliku Deus caritas est, jejíž část dokonce nedávno vyšla tiskem. Viz Jakub DOLEŽEL, Teoretické ukotvení církevní sociální práce na pozadí obecných a českých charitních dějin až po encykliku Deus caritas est, disertační práce, Cyrilometodějská teologická fakulta, Univerzita Palackého v Olomouci, Olomouc, 2011, vedoucí práce Heinrich Pompey; dále viz Jakub DOLEŽEL, Církevní sociální práce na pozadí encykliky Deus caritas est, Olomouc: Univerzita Palackého v Olomouci, 2012, 152 s.

Ve druhé kapitole své disertační práce Doležel sepsal přehled historické tradice charitní praxe církve s důrazem na domácí tradici. Viz kap. 2 s názvem Historická tradice charitní praxe církve v naší zemi na s. 54-203. Podkapitoly mají název Církevní sociální práce jako téma historického bádání, Stručný nárys obecných dějin církevní sociální práce a Kličové momenty církevní sociální práce v naší zemi. Ačkoli jeho téma není shodné s tématy bohatstuí a bohatých v dějinách církve, jsou si obsahově poměrně blízko - z Doleželova textu lze bez potíží vybrat jakési hlavní body toho, jak se církev ve své tradici a v dílech svých významných osobností dívala na bohaté a bohatství v běhu času, tj. od období starověku prakticky po současnost. Nejde mi o kritiku tohoto autora, zvláště když těžiště jeho práce přece jen bylo někde jinde, ale právě na jeho snaze o dějinný přehled - který je vytvořený pouze na základě primární a především sekundární literatury - je možné ilustrovat, že nehistorik by se měl mít na pozoru před tím, aby se nepouštěl do neznámých vod.

Avšak Doležel nezůstal pouze u zmíněného dějinného přehledu, protože se v dílčích souhrnech v rámci podkapitol $2.1,2.2$ a 2.3 i v celkovém shrnutí celé druhé kapitoly (s. 199-203) pokouší o nalézání jakýchsi „modelů charitní práce“. Viz Jakub DOLEŽEL, Teoretické ukotveni církevní sociální práce.

Dovoluji si tvrdit, že bez řádně provedeného historického výzkumu nemají Doleželovy vývody valnou hodnotu.

Avšak abych právě Doleželovi nekřivdil, musím zmínit, že v jiné své publikaci si je svých omezení při bádání vědom, jak např́iklad ukázal ve studii Jakub DOLEŽEL, Církevní sociální práce jako téma historického bádání, in: Spravedlnost a služba IV, ed. Dita PALAŠČÁKOVÁ, Olomouc: CARITAS-VOŠ sociální Olomouc, 2010, s. 63-76, ve které zprostředkoval vědecké obci pohled na církevní charitativní práci v knize Willibalda Ladenbauera. Viz Willibald LADENBAUER, Das sociale Wirken der katholischen Kirche in der Diöcese Budweis, Wien, 1899.

6 Ve 20. století například reprezentantu francouzské školy Annales Fernandu Braudelovis pomocí koncepce „longue durée“. 
již několik let a navazují na podobné debaty v zahraničí. Jako výstupy těchto diskusí jsou veřejnosti dostupné především publikace Ekumenické církevní dějepisectví (2003) ${ }^{7}$ a Eseje o povaze církevních dějin (2012). ${ }^{8}$ Do obou přispěli kromě dalších odborníků např. historici Jiří Hanuš a František X. Halas nebo teologové Pavel Ambros a Jaroslav Vokoun. Celkově se dá říci, že obě knihy ukazují zcela jednoznačně, že pokoušet se dělat obecné přehledy v církevních dějinách nemá smysl. Jinak řečeno: zcela komplexní a vyčerpávající církevní dějiny prostě „udělat" není možné, protože dřive či později narazí autor na takové komplikace, které nedokáže sám překonat. Ty jsou dány nejen samotnou již výše zmíněnou složitostí poznání jednotlivých epoch, ale třeba i tím, že existují různé historické školy nebo pojetí dějin dané např. (ne)příslušností autora k té které konfesi. Analogicky všechna tato tvrzení platí i pro nyní řešené problematiky bohatství, bohatých nebo ještě užší problematiku pastorace bohatých.

Domnívám se, že kdybychom s našimi tématy oslovili např. deset církevních historiků, každý přijde s jiným zpracováním. To bude dáno nejen odlišným vnímáním některých období dějin církve i konkrétních církevně-historických či dějinně-teologických témat díky jejich možné (již zmíněné) různosti konfesního zaměření nebo jiného ideového zakotvení, ale také tím, že žádný z nich nemůže být specialistou na celé dva tisíce let dějin křest'anství. Samozřejmě, že by $\mathrm{v}$ nich měl mít každý církevní historik více než jen dobrý přehled, stejně tak v obecných dějinách, $v$ dějinách teologie, v kulturních dějinách atd., ale obvykle se úžeji zaměřuje jen na jejich část - podobně jako lékař zná dobře lidské tělo a v základu i všechny medicínské obory, avšak k atestaci si vybírá konkrétní specializaci, ve které se pak po celou svou profesní kariéru zdokonaluje. Zcela jistě by se také ukázalo, že zpracování různých epoch bude velmi odlišné co do hloubky: někde již díky vysokému zájmu o danou dobu a dřivějším historickým a teologickým výzkumům bude na co navazovat, jinde bude badatel začínat prakticky od nuly. Každopádně se domnívám, že diskuse mezi církevními historiky, kteří by se našimi tématy zabývali, by měla předcházet další mezioborové diskusi nebo jít - pokud to bude třeba souběžně s ní.

Jsou situace, kdy má smysl široké dějinné přehledy dělat i u tak speciálních témat jako jsou bohatstuí a bohatí $v$ dějinách církve nebo pastorace bohatých $v$ dějinách, např̀. ve výuce studentů zaměřených na křest'ansky motivovanou sociální a charitativní práci nebo pro frekventanty kurzu praktické teologie. Na obecném přehledu je také možné zdařile naznačovat množství slepých uliček $\mathrm{v}$ badatelské práci - což vůbec není špatný zpo̊sob pro první seznámení se $\mathrm{s}$ tématem nebo pro příspěvek na symposiu, kde jsou přítomní kolegové $\mathrm{z}$ jiných teologických nebo teologii př́ibuzných oborů či jiní posluchači, které by tematicky př́liš úzce zaměřený příspěvek mohl nemile překvapit. Jinak řečeno: přestože pro hlubší pojednání celé problematiky tento zpơsob není vhodný, získat obecný vhled (nebo jej předat) bývá v některých situacích zapotřebí. Také proto chci čtenáře upozornit, že základní všeobecné informace ke zmíněným tématům je možné najít nejen v již zmiňované Doleželově práci, ${ }^{9}$ ale také v dílech převážně zahraničních autorů, jako např. Herberta Haslingera, Gottfrieda Hammanna nebo Markuse Lehnera. ${ }^{10} \mathrm{Z}$ toho je zřejmé, že hledal-li by čtenář informace o bohatství, bohatých či

\footnotetext{
7 Jiří HANUŠ (ed.), Ekumenické církevní dějepisectví, Dějiny, analýzy, perspektivy, Brno: CDK, 2003. Za přečtení stojí především úvodní studie Berndta Jasperta, na kterou posléze další autoři přímo či nepřímo reagují.

8 Jiří HANUŠ (ed.), Eseje o povaze církevních dějin, Brno: CDK, 2012. Tato publikace je do jisté míry i zhodnocením toho, kam se diskuse posunula od vydání Ekumenického církevního dějepisectví, tj. cca za deset let.

9 Právě Doležel předkládá aktuální bibliografii domácích a zahraničních autorů, kteří mají k našemu tématu velmi blízko. Viz Jakub DOLEŽEL, Teoretické ukotvení církevní sociální práce.

10 Herbert HASLINGER, Diakonie. Grundlagen für die soziale Arbeit der Kirche, Paderborn-Munchen-Wien-Zürich: Ferdinand Schöningh, 2009; Gottfried HAMMANN, Die Geschichte der christlichen Diakonie. Praktizierte Nächstenliebe von Antike bis zur Reformationszeit, Göttingen, 2003; Markus LEHNER, Caritas: Die Soziale Arbeit der Kirche, Freiburg: Lambertus, 1997.

Dále je také zajímavé pro základní orientaci nahlédnout do děl těchto autorů: Herbert KRIMM (ed.), Quellen zur Geschichte der Diakonie. 3 Bd., Stuttgart, 1960-67 nebo Rosario MESSINA, Dějiny charitativní činnosti, Kostelní Vydří: Karmelitánské nakladatelství, 2005.
} 
pastoraci bohatých $\mathrm{v}$ kontextu dějin církve, je tato problematika zpracována především $\mathrm{v}$ dílech autorů věnujících se dějinám pastorace a také křest'anské sociální a charitativní práci. Témata jsou zpracovávána především tam, kde je pozornost věnována chudobě a chudým - jedná se o témata neoddělitelná a navzájem úzce propojená.

Z výše uvedených úvah je možné učinit závěr: Je lépe, když autor zpracuje - třebaže dílčím způsobem a $z$ omezeného pohledu své odbornosti - méně rozsáhlé téma, které přesněji vymezí časově, geograficky atd., než aby se pokoušel vytvářet obecný přehled, který ze své podstaty nikdy nebude ani zcela obecný ani vyčerpávající. Věnovat se dílčí problematice má samozřejmě také svá pravidla a úskalí. Badatel si musí být vědom limitů daných vlastní osobou i samotným tématem, které hodlá zpracovat - a otevřeně na ně čtenáře upozornit. Takto zpracované téma pak může být vážněji míněným příspěvkem pro další diskuse. $\mathrm{V}$ tomto smyslu by měla být chápána i tato studie.

\section{Zneužití tématu bohatství v časopise Charita}

\section{Katolická církev jako ideologický nepřitel KSČ}

O tématu postupného přebírání moci komunisty v poválečném Československu toho již bylo napsáno relativně mnoho. Přesto se zatím nejedná o téma ani zdaleka vyčerpané co do obsahu i co do nutnosti neustálého připomínání - a to zejména př́islušníkům nejmladší generace, kteří vnímají tuto dobu jako velmi vzdálenou a jen s obtížemi si dokáží představit, v jak složité situaci se ocitali ti, kteří svým náboženským nebo politickým směřováním stáli v cestě nastupující totalitě. Je nutné stále opakovat fakt, že komunisté se k moci dostávali postupně od vyhraných voleb v roce 1946 přes únorový převrat 1948 až k následnému upevňování pozic v kdysi demokratickém státě, které bylo spojeno s čím dál tvrdší perzekucí protivníků.

Je známo, že KSČ považovala za jednoho ze svých úhlavních ideologických nepřátel katolickou církev, která byla zejména co do počtu nejvýznamnějším představitelem křest'anských společenství v tehdejším Československu. Není proto divu, že se zvláště po únoru 1948 katolická církev ocitla pod stále sílícím tlakem, jehož součástí byly přímé i nepřímé útoky státní moci. Jednalo se o součást zmíněného procesu upevňování pozic a dalšího přebírání moci. Velkou roli v něm hrál i boj o ovládnutí institucí patřících pod správu katolické církve. Právě jejich prostřednictvím chtěla statní moc získat na svou stranu některé katolíky. Jako ideální platforma se pro tento úmysl zdály být vybrané „katolické“ noviny, časopisy či jiné tiskoviny, které komunisti získali pod svoji kontrolu (když předtím vydávání těch skutečně katolických zakázali). Dílčí fakta o tom představili ve svých studiích například Karel Kaplan, ${ }^{11}$ Václav Vaško, ${ }^{12}$ editoři Jan Paulas s Jaroslavem Šebkem ${ }^{13}$ nebo Martin Weis. ${ }^{14}$

\section{Časopis Charita v letech 1946-1951}

Jedním takovým povoleným časopisem byla i Charita. Protože proměnám tohoto časopisu se již podrobně věnuje jiná současná studie, ${ }^{15}$ dovolím si představit již jen stručné shrnutí: Charita začala vycházet od roku 1946 nejprve jako dvoutýdeník s podtitulem časopis pro sociální

\footnotetext{
Uznávaná přehledová práce o bohatých v církvi nebo o pastoraci bohatých zatím není k dispozici.

11 Karel KAPLAN, Stát a církev v Československu v letech 1948 - 1953, Brno: Nakladatelství Doplněk, 1993.

12 Václav VAŠKO, Neumlčená, Kronika katolické církve v Československu po druhé světové válce, sv. 1, Praha: Zvon, 1990.

13 Jan PAULAS - Jaroslav ŠEBEK (ed.), Katolické noviny 1949-1989, Katolický týdeník, Praha: Katolický týdeník, 2009.

14 Martin WEIS, „Katolická církev ve světle Věstníku katolického duchovenstva,“ Studia theologica 13, č. 1 [43] (2011), s. 80-98.

15 Rudolf SVOBODA - Jan HENDRYCH, „Časopis Charita a jeho proměny v letech 1946-1951“, Studia theologica 15, č. 4 (2013), s. 35-46.
} 
a zdravotní práci. Vydávána byla katolickou Charitou. ${ }^{16} \mathrm{~V}$ prvních dvou letech své existence se ideově i obsahově jednalo o katolický časopis, který svým čtenářùm představoval sociální a charitativní aktivity katolické církve v poválečném Československu i v zahraničí. Ve vedení se nacházeli katolické církvi loajální duchovní. ${ }^{17} \mathrm{Když} \mathrm{si} \mathrm{po} \mathrm{únorovém} \mathrm{převratu} \mathrm{dali} \mathrm{komunisté}$ za cíl pomocí sympatizantů z řad duchovních prorůst do církevních struktur a použít je ke svým účelům, ${ }^{18}$ došlo v tomto duchu již velmi brzy také k zásahům do vedení katolické Charity. V dubnu 1948 byla zavedena tzv. Národní správa v Ústředí svazu katolické Charity. Tato správa byla tvořena kněžskými spolupracovníky nového režimu: Josefem Františkem Fialou, Josefem Kloučkem a Josefem Plojharem. Na pokyn vedení KSČ toto nové vedení začalo vyvíjet snahy o dosazení vlastních lidí do jednotlivých institucí Charity. Následné ostré protesty biskupů proti omezování církevních práv na vykonávání charitní činnosti měly pouze omezený účinek: ${ }^{19}$ KSČ se sice nepodařilo dostat své lidi do čela všech církevních charitativních institucí v Československu, ale v samotném vedení Charity zůstali lidé novému režimu oddaní - Eduarda Oliva, Jan Mára a Josef František Fiala. ${ }^{20}$

Změny ve vedení katolické Charity měly vliv také na stejnojmenný časopis, který byl - jak bylo výše řečeno - právě touto institucí vydáván. Přestože po obsahové stránce ještě v prủběhu roku 1948 zůstal politicky neutrální, resp. držel se převážně témat, která odpovídala zaměření časopisu, tato svoboda netrvala dlouho: na počátku ledna 1949 bylo zastaveno vydávání veškerých římskokatolických časopisů kromě lokálního polského $W$ obranu pravdy a úředních věstníků pro jednotlivé diecéze - Acta curiae, dále Katolického týdeníku a časopisu Charita. ${ }^{21}$ Ten měl vycházet nadále $\mathrm{v}$ třicetitisícovém nákladu jako týdeník ${ }^{22}$ a měl se věnovat sociální péči i náboženskému a církevnímu životu. Redakci měl vést Josef František Fiala. ${ }^{23}$ Jinak řečeno se měl časopis Charita stát v rukou KSČ účinnou zbraní v již zmíněném boji o veřejné mínění katolíků. ${ }^{24}$

Od této chvíle se na stánkách časopisu začalo objevovat velké množství proletářské a tzv. mírové problematiky, ve které byla zdůrazňována zejména role Sovětského svazu jako osvoboditele a garanta míru. Pisatelé článků si také dávali záležet na tom, aby ukazovali podobnost komunistických ideálů s Ježíšovým učením. Jak v průběhu roku 1949 docházelo ke změnám v církevní politice státu, ${ }^{25}$ proměňoval se i obsah časopisu, který byl stále intenzivněji

16 Přesněji řečeno bylo vydavatelem Ústředí svazů katolické Charity v Praze. Viz tiráž historicky prvního čísla časopisu: Charita, časopis pro sociální a zdravotní práci (dále jen Charita) 1, č. 1 (1946). Srov. také VAŠKO, Neumlčená, sv. 1, Praha: Zvon, 1990, s. 189. Způsoby použivání názvů katolická Charita nebo Ústředí svazủ katolické Charity lze najít např̀ ve výše zmíněných studiích Václava Vaška, Karla Kaplana nebo Martina Weise. Protože se jedná již o způsob zavedený, v této studii se ho také přidržím.

17 Srov. SVOBODA - HENDRYCH, Časopis Charita, s. 36-37.

18 Kromě výše i níže zmiňovaných knih Václava Vaška a Karla Kaplana může čtenář využít pro prozkoumání této problematiky např. také studii slovenského historika z bratislavské univerzity Róberta Letze. Viz Róbert LETZ, „Postavenie Katolické církvi v Československu v rokoch 1948-1989," in Kř̌žž pod rudou hoězdou, ed. Martin WEIS, Rudolf SVOBODA, České Budějovice: Jih, 2009, s. 42-77, zde zejména s. 51-61. 19 Srov. Václav VAŠKO, Neumlčená, Kronika katolické církve v Československu po druhé světové válce, sv. 2, Praha: Zvon, 1990, s. 46-47; SVOBODA - HENDRYCH, Časopis Charita, s. 37-38.

20 Všichni tři se stali členy prorežimní státní „Katolické akce“, která byla založena v červnu 1949. O státní „Katolické akci“, jejích plánech i o reakci biskupů podrobně vypráví VAŠKO, Neumlčená, sv. 2, Praha: Zvon, 1990, s. 67-78. Krátké životopisy těchto tří mužů viz SVOBODA - HENDRYCH, Časopis Charita, s. 38-40.

21 O jak obrovský a zásadní zásah se jednalo, ilustruje skutečnost, že na počátku roku 1948 vycházelo na území Československé republiky 133 církevních a náboženských časopisů. Jejich činnost byla postupně omezována. Zmíněný zákaz byl pomyslnou tečkou za tímto procesem. Srov. Vojtěch NOVOTNÝ, Teologie ve stínu. Prolegomena k dějinám české katolické teologie druhé poloviny 20. století, Praha: Univerzita Karlova v Praze, Nakladatelství Karolinum, 2007, s. 97-98.

22 Rozhodnutí vydávat Charitu jako týdeník se nikdy nerealizovalo, v následujících letech vycházela jako měsíčník.

23 Viz Př́loha 3 „Úprava církevního tisku na rok 1949“ v knize KAPLAN, Stát a církev, s. 288-289; NOVOTNÝ, Teologie ve stínu, s. 99.

O šiři českého a slovenského katolického tisku před rokem 1948 pojednává podrobněji Václav Vaško. Viz VAŠKO, Neumlčená, sv. 1, s. 188-192.

24 Tento zápas ukazuje Zápis ze schůze širšího představenstva ÚV KSČ z 25. dubna 1949. Srov. KAPLAN, Stát a církev, s. 351; SVOBODA - HENDRYCH, Časopis Charita, s. 38-41.

$25 \mathrm{~K}$ důsledkům těchto změn patřila např. internace pražského arcibiskupa Josefa Berana v červnu 1949 - krátce nato se ocitli v internaci prakticky všichni diecézní biskupové, dále vydání tzv. církevních zákonů na podzim téhož roku, kterými byla církev podřízena přísné 
využíván ke komunistické propagandě. Na přelomu let 1949 a 1950 došlo k posledním změnám ve vedení redakce, do jejíhož čela nastoupili kovaní komunisté - a obsah časopisu se proměnil ještě více. Zatímco do této doby v časopise přece jen převládaly církevně-charitativní otázky, pouze některé články byly spíše budovatelské než sociálně-křest’anské a komunistická propaganda existovala "mezi řádky“", nyní se časopis stal jednoznačně "hlásnou troubou“ komunismu. ${ }^{26}$ Tomu samozřejmě odpovídala církevně-politická realita $\mathrm{v}$ komunistickém Československu v těchto letech, která jsou právem považována za nejtvrdšíi. ${ }^{27}$

V roce 1951 - tj. posledním roce svého vycházení - stál časopis zcela ve službě režimu: hlavními tématy se místo pomoci druhým stál mír ohrožovaný kapitalisty ze západu, články jsou plné obdivu k Sovětskému svazu, Stalinovi, KSČ a Gottwaldovi. Rozhodnutí o ukončení vydávání tohoto periodika je třeba chápat v kontextu zásahů státu proti katolické církvi v předešlých třech letech. ${ }^{28}$ Samotná katolická Charita, která časopis vydávala, se jako instituce stala víceméně pouhou „odborovou organizací“ pro loajální představitele katolické církve. Zajišt'ovala např̀. rekreace duchovních, provozovala výrobny a prodejny devocionálií. Pod hlavičkou katolické Charity se nalézala také místa internace nepohodlných duchovních. ${ }^{29}$

\section{Téma bohatstoí na stránkách časopisu a jeho zneužitî}

V předúnorových vydáních časopisu Charita, resp. do převzetí státní kontroly nad katolickou Charitou v dubnu 1948, se sice nikde o bohatstuí nebo bohatých explicitně nehovoří, avšak je patrné, že cílem redakce bylo ukázat posluchačům, co všechno se dělá pro potřebné, popřípadě jakým způsobem se ostatní zapojují do pomoci v těžkých poválečných časech - zcela jistě se záměrem inspirovat ty, kteří by mohli pomoci. Časopis vyzývá všechny lidi dobré vůle ke společné práci, resp. charitativní činnost chápe jako společný úkol všech - zejména věřících. Ani náznakem nestaví bohaté a chudé proti sobě. Naopak jsou prakticky v každém vydaném čísle zdůrazňovány příklady dobré praxe těch, kteří pomohli, a také těch, kteří jsou za tuto pomoc vděčni. Dalo by se říci, že jako „bohatý“ není chápán pouze ten, kdo má peníze, ale i ten, kdo věnuje svoje schopnosti a svůj čas dobrému dílu. Zcela jistě lze v tomto smyslu chápat časopis i jako specifickou (plat)formu pastorace bohatých, tj. těch, kteří pomáhají lidem, kteří v životě neměli tolik štěstí.

Podobné to bylo i v druhé polovině roku 1948 a v roce 1949: téma bohatství se prakticky nevyskytuje, časopis se zabýval tématy a měnil se způsobem, který jsem zmínil výše - tj. Charita přestávala sloužit svému původnímu účelu a stávala se hlásnou troubou komunistické propagandy.

Teprve v roce 1950, tj. po radikálních změnách v redakci, se bohatstuí stalo na stránkách Charity jedním z velmi frekventovaných témat. $V$ deseti číslech, které v tomto roce vyšly, se objevovalo vždy v úzkém spojení s náboženskou problematikou. Obecně se dá říci, že bohatství je ostře

kontrole státu. Současně se už chystalo masivní pronásledování, na konto brutality Státní bezpečnosti jsou připisováni první mrtví z řad duchovních. Vznikl také Státní úřad pro věci církevní a posty církevních tajemníků, kteří měli monitorovat všechny náboženské aktivity. O jejich vzniku hovoří Martin Weis ve studii: Martin WEIS, „,Okres na Jihu. Sonda do práce okresních církevních tajemníků ve světle archivních dokumentů jihočeského regionu," Studia theologica 13, č. 3 [45] (2011), s. 89-91.

26 Velmi podobně v této době psaly také Katolické noviny. Viz. PAULAS - ŠEBEK, Katolické noviny 1949-1989, s. 10-39; SVOBODA HENDRYCH, Časopis Charita, s. 31-42.

27 Právě v této době byly zahájeny monstrprocesy s vysokými církevními hodnostáři, byla výrazně omezena činnost všech mužských a ženských řeholí, kláštery byly zabrány a členové řeholí internováni. Uvězněno bylo velké množství kněží. Viz např. VAŠKO, Neumlčená, sv. 2, s. 109nn. Podobně se touto problematikou zabývá KAPLAN, Stát a církev, s. 111nn; SVOBODA - HENDRYCH, Casopis Charita, s. $42-43$. 28 Vojtěch Novotný, který podrobně představil postup likvidace katolického tisku od roku 1948, došel v podobném kontextu k názoru, že cílem komunistů bylo nejprve vybraná periodika zneužít a následně zlikvidovat. Viz NovotNÝ, Teologie ve stínu, s. 101, v širším kontextu 97-101. 29 Viz Martin WEIS, „Nebezpečný svatý Jan Nepomuk Neumann,“ Studia theologica 12, č. 2 [40] (2010), s. 20-34, zde zejména pozn. 10; Edita MENDELOVÁ, „Perzekuce ženských řeholí v r. 1950,“ in Stát a církev v roce 1950, ed. Jiří HANUŠ, Jan STŘíBRNÝ, Brno: CDK, 2000, s. 84-85; Jindřich Zdeněk CHAROUZ, „Internační tábor Želiv,“ in: Stát a církev v roce 1950, ed. Jiří HANUŠ, Jan STŘÍBRNÝ, Brno: CDK, 2000, s. 68-83, zde zejména s. 73-78; VAŠKO, Neumlčená, sv. 2, s. 190-191; SVOBODA - HENDRYCH, Časopis Charita, s. 43-45. 
kritizováno a stejně tak jeho nositelé - bohatí, kteříjsou ztotožňováni s kapitalismem, buržoazií, šlechtou a církevní hierarchií, jinak řečeno s nepřáteli komunismu.

Pisatelé článků, kteří jsou někdy anonymní nebo se podepisovali iniciálami, představují čtenářům téma bohatství jako teologický problém - argumentují nejčastěji biblickými texty, z nichž vyvozují jednoznačné morální odsudky. Postup argumentace je u všech článků velmi podobný: správné křest́anství je takové, ve kterém je na prvním místě chudý člověk - stejně jako u komunismu. Mezi řádky se tudíž dá číst, že pravý křest'an je komunista. Následně je odsouzena praxe bohatých, kteří jsou viděni jako špatní křest'ané a zároveň jako nepřátelé komunismu.

Při argumentaci proti bohatství a bohatým jsou často využívány velké postavy křest'anství. V tomto směru je třeba zmínit zejména článek Josefa Vlastimila „Běda vám, bohatí““ ${ }^{30}$ Autorv něm vykresluje obraz chudoby, hladu a nezaměstnanosti mnoha lidí ve světě západních velkoměst, kde si bohatí hledí jen svého majetku a chudí zaměstnanci se krčí v chatrčích bez pomoci. Tvrdí, že v těchto městech mnoho chudých umírá v bídě, zatímco jejich bohatší spoluobčané pořádají velkolepé hostiny ve velkých hotelech - zatímco americká armáda vraždí ženy a děti v Koreji. Poté předkládá řadu tvrzení pro to, aby ukázal, co si myslel o bohatství samotný Ježíš a zároveň dokazoval, že byl první socialista: jednoznačně řekl bohatému mládenci, že pokud chce být dokonalý, musí prodat svůj majetek a rozdat jej chudým; dále pravil, že těžko vejdou do Božího království ti, kdo hromadí peníze - a stejně tak ti, kteří spoléhají na svůj majetek. O chudobě kázal také v Kázání na hoře. Neustále prý naznačoval, že velký majetek je překážkou spasení: "Tak musíme rozuměti jeho slovìm, jimiž hřmí do duší boháčů: ,Běda Vám, bohatí!" (Lukáš 6,24). Jako by chtěl říci: ,Běda vám, kteří s lehkým srdcem se díváte na své dělníky, jež mají sotva na kus suchého chleba, snižujete jejich výdělky a sami hodujete!" "31 Autor zmiňuje, že Ježíš neodsuzoval poctivě nabytý majetek a dokonce se s některými zámožnými lidmi i stýkal, tj. neodsuzoval bohaté proto, že jsou bohatí, ale proto, že nepomáhali chudým. Právě lásku k bližnímu Kristus prohlásil za hlavní základnu svého království. Láska k bližnímu má být motorem sociálního cítění a působení podle evangelia. Jedině ta povede bohaté, aby spravedlivě odměňovali práci svého bližního. Jako další tvrzení je čtenáři předkládáno, že církev v minulosti přikázání Krista nectila a na lásku k bližním zapomínala - přestože přikázání lásky k druhému platí dodnes. Následuje "aktualizace“, která je již čistou propagandou: "V děrách a boudách tlačí se na Západě nebo v koloniích nezaměstnaní ubožáci bez lékaře v hadrech, za kousek suchého chleba s prídavkem nadávek a opovrženi, a bez ochrany a soucitu vrstev, kterým by drahocenné lidské životy měly býti více, než žoky naplněné dolary. Kořistníci mají však odvahu skrýti se za Kristovo evangelium jako za zástěnou. Jak dobře jest nám v naší republice! Není nezaměstnaných, ani hladových, není postav $v$ hadrech. ... A komu máme za to děkovat? Jedině Bohu a našemu pracujícímu lidu. Je to jeho zásluha a zásluha naši vlády, která se o pracující lid moudře stará. Radostně pracovat, radostně sklízet a radostně žít, jsou hesla naší doby. Zářným vzorem budiž nám všem Sovětský svaz. "32 Podobně vypovídající je i závěr: „Uvažovali jsme společně, co soudil Kristus o majetku. Poznali jsme, že Kristova nauka neodporuje v ničem dnešnímu sociálnímu zř́zení. Naopak, podporuje ho". ${ }^{33}$

Jiný autor, Pavel Martin, zase ukazuje Ježíše jako dělníka, stejně tak i apoštoly. Cituje Jakubovu epištolu, kde horlí proti bohatým hlavně jako proti těm, kteří zadržují dělníkům jejich zaslouženou mzdu. ${ }^{34}$

\footnotetext{
30 Srov. Josef VLASTIMIL, „Běda vám, bohatí,“ Charita 5, č. 8 (1950), s. 5-6.

31 Tamtéž, s. 5.

32 Tamtéž, s. 5-6.

33 Tamtéž, s. 6.

34 Srov. Pavel MARTIN, „Práce je požehnáním,“ Charita 5, č. 4 (1950), s. 18.
} 
Jinde zase při příležitosti adventu hovoří Josef Ambrož o poslání Ježíše Krista vysvobodit lidstvo z duševní a mravní bídy: "Nádherné paláce, sochy, obrazy, knihy velkých básníků - to vše tvořilo toliko velkolepou kulisu pro drama vykořistování člověka člověkem ... imponujicí postavy slavných básniků a filosofü tehdejší doby jsou toliko propagační nástroje politického a hospodářského útisku. "35 Ježíš hlásal rovnost a svornost všech lidí a národů a bojoval za chudé, takže je naším vzorem. ${ }^{36}$

V posledním vydání časopisu z roku 1950 se nachází jakoby tečka za celoročním přetřásáním tématu "Co si myslel o bohatství Ježíšc článek "Svatá noc, tichá noc..." s krásným obrázkem jesliček. Po barvitém slovním vyobrazení Ježíšova narození napsal anonymní autor toto: „Kdo byli ti, které Bưh vyznamenal a dal jim spatřiti Vykupitele? Chudí pastýři to byli! Opatrujice tučná stáda bohatců, neměli za svou lopotu mnohdy ani tolik, aby své rodiny dostatečně nasytili... Nám, nám narodil se... Pro budoucí křstáanský svět, tedy i nám a pro nás se narodil bojovník za prostá lidská práva a za spravedlivý ř́d. ON to byl, který jasně ř ekl: ,Dřive projde velbloud uchem jehly, než jediný bohatec branou ráje..."

Jako bojovník proti bohatým je představován i Jan Křtitel. ${ }^{38}$ Josef Vlastimil zase na jiném místě využívá postavu sv. Vojtěcha, který je ukázán jako někdo, kdo poznal „....chabost životních zásad stavěných na bohatství a moci z bohatstoi a titulů plynoucí."39 Přestože to byl biskup a šlechtic, stal se prý vzorným synem českého lidu: dovedl se živit prací svých rukou, nedal se zlákat nádherou ani přízní dvora a zastával se lidu. Do úst mu autor dokonce vkládá výzvu: „Nevěřte licoměrným slibům kapitalistické společnosti, ale pojd'te za mnou, za Vojtěchem, mojí cestou pravdy, cestou, která vedla k slovanskému východu. "40

O bohatství se psalo také při zdưrazňování tzv. mírových aktivit. Horlení za mír bylo dáváno do souvislostí s těmi, kteři chtějí válku: nenasytnými a chamtivými kapitalisty. ${ }^{41}$ Ukrutnost bohatých je ukazována např. na "strašlivých" poměrech v amerických porodnicích - ve srovnání s československými: americké porodnice z matek a jejich rodin jen vysávají peníze, nepostarají se o ženu v nouzi, protože na obyčejném člověku jim nezáleží, tj. postarají se jen o boháče. Naopak v Československu je vše zadarmo, cílem je zdraví matky a dítěte. ${ }^{42}$ Jinde je možné najít tvrzení, že bohatým - kapitalistům a buržoazii - nikdy nezáleželo na zdraví lidu, protože postarat se o potřebné by bylo drahé. Opět je dáván do popředí stát, který se o své chudé postará. ${ }^{43}$

Tématika bohatstvíje zmiňována také v souvislosti s úvahami o duchovních: v článku „Křest'ané a práce" se objevují odpudivé obrazy líných kněží v kancelářích a řeholníků v klášterech pořádajících hody a holdujících jen svým „objemným tělům“, kteří si v bohatství a bez práce žijí na úkor ostatních. Anonymní autor textu vyzývá duchovní, aby šli „na vinici Páně“, šli pracovat pro Boží království - klášterní život proto jednoznačně odmítá. ${ }^{44}$ Když už jsou jinde např. chváleni Milosrdní bratři v Praze za to, že se po léta obětavě starali o nemocné a umírající, „...když na ně bohatci zapomínali a jimi opovrhovali“ , stejně je jejich způsob péče viděn jako relikt

\footnotetext{
35 Josef AMBROŽ, „Advent a jeho poslání“, Charita 5, č. 9 (1950), s. 4-5.

36 Srov. tamtéž.

37 „Svatá noc, tichá noc...", Charita 5, č. 10 (1950), s. 4-5

38 Srov. M. Hc. „Osobnost svatého Jana Křtitele“, Charita 5, č. 6 (1950), s. 12.

39 Josef VLASTIMIL, „Cesta svatého Vojtěcha“, Charita 5, č. 4 (1950), s. 6-7.

40 Tamtéž, s. 7.

41 Srov. „Mír zárukou štéastné budoucnosti“, Charita 5, č. 5 (1950), s. 19. Článek byl napsán podle projevu J. Plojhara.

42 Srov. Anežka CHMELÍKOVÁ, U nich a u nás, Charita 5, č. 7 (1950), s. 15.

43 Srov. Karel MENŠíK, „Lid má právo na zdravi““, Charita 5, č. 3 (1950), s. 16; Pavel MARTIN, „Nový pohled na nemocnici Milosrdných bratří v Praze“, tamtéž, s. 19.

44 Srov. XY, „Křest'ané a práce“, Charita 5, č. 6 (1950), s. 6.
} 
minulosti, protože současný stát se stará mnohem lépe o kohokoli, kdo to potřebuje. ${ }^{45}$ Alexandr Horák v článku „Rímskokatoličtí kněží v boji za mír“ zdůrazňuje nejen nevyhnutelnost spolupráce duchovních s vládou na cestě $\mathrm{k}$ socialismu, ale hovoří o Božím záměru, který měl př̀i Stvoření, a to „bonum commune“, obecné dobro. Na základě toho autor kritizuje ty, kteří si žijí na úkor ostatních a získávají majetek náhodou, lstí, lakomstvím, dědictvím nebo prvorozenstvím. Kritizuje také hierarchické uspořádaní církve, které neodměňovalo chudé duchovní (řazené mezi dělníky!) podle jejich práce, narozdíl od současného stavu, kdy duchovní podle jejich zásluh odměňuje stát. ${ }^{46}$ Eduard Oliva zase v článku „Potřebujeme kněze“ dává do přímé souvislosti život v bohatství a nízká kněžská povolání. ${ }^{47}$

Zbývá ještě dodat, že v posledním roce svého vycházení se časopis tematicky posunul spíše ke zdưrazňování míru, k obdivu Sovětského svazu a k proklamování věrnosti KSČ. Náboženská problematika již měla marginální postavení, převládala zejména témata zdravotní a politická. ${ }^{48}$ Kritika bohatství se již na stránkách časopisu prakticky neobjevovala. ${ }^{49}$ Je to vcelku logické: skončila fáze, ve které se komunisté snažili získat na svou stranu některé věřící tím, že se pokoušeli ukazovat slučitelnost křestáanství s komunismem. Boj vedený proti církvi se již měl prakticky za vyhraný a bylo možné postupně přecházet k další fázi plánované likvidace.

\section{Několik slov závěrem}

Význam časopisu Charita je možné spatřovat v tom, že je konkrétním příkladem a svědectvím postupné likvidace církevních aktivit komunistickým režimem po únorovém převratu. Dílčím způsobem ukazuje postupné prorůstání komunistických sympatizantů do církevních struktur a jejich následné využití pro své účely. Platforma časopisu pomáhala po určitý čas komunistické propagandě. Jeho zánik byl logickým vyústěním ideologického boje mezi katolickou církví, respektive křest'anstvím, a KSC, respektive komunismem.

Otázka zneužití tématu bohatství v časopise Charita je vlastně jedním velkým paradoxem, protože toto téma se řešilo v časopise, který měl od svého vzniku primárně za cíl věnovat se potřebným. Kněží ve službách komunistického režimu zde používali křest'anskou tématiku k tomu (někdy snad i ne zcela vědomě), aby pomohli vítězství KSČ nad katolickou církví v tomto duchu byla zneužívána i témata bohatstuí a bohatých.

Smutné je to, že i ona propaganda byla z pohledu těch kolaborujících kněží, kteři časopis vedli a dalších, kteří byli autory článků, svého druhu „pastorací“, ačkoli doslova postavenou na hlavu. V jejich podání se ovšem jedná o pastoraci tak zpolitizovanou, ideologicky zmanipulovanou, zjednodušující a černobíle pojatou, že nebýt tak závažného dějinného kontextu, mohly by být některé "výkřiky“ oněch kněží brány jako docela humorné. V jejich rukou se zásadní téma pomoci potřebným stalo v roce 1950 kritikou bohatých, a ti byli ztotožněni ponejvíce s ideologickými nepřáteli: s kapitalismem, buržoazií, církevní hierarchií, s USA. Především významné postavy křest́anských dějin - zejména samotný Ježíš - byly zneužity v boji Východu proti Západu, komunismu proti kapitalismu, chudých proti bohatým. Nástrojem

45 Srov. Pavel MARTIN, „Nový pohled na nemocnici Milosrdných bratří v Praze“, Charita 5, č. 3 (1950), s. 19-20, cit. s. 19.

46 Srov. Alexandr HORÁK, „Ǩímskokatoličtí kněží v boji za mír“, Charita 5, č. 8 (1950), s. 9; v podobném duchu je také článek František TRIPSKÝ, „,Rok církevních zákonü“, Charita 5, č. 10 (1950), s. 15.

47 Srov. Eduard OLIVA, „Potřebujeme kněze“, Charita 5, č. 8 (1950), s. 11-12.

48 Srov. SVOBODA - HENDRYCH, Časopis Charita, s. 43-45.

49 Náznaky je ještě možné spatřit v článku Eduard OLIVA, „Katolický kněz v čele hnutí obránců míru,“ Charita 6, č. 1 (1951), s. 13-14, kde autor hovoři o nespravedlivém míru, který se snaží kapitalisté vnutit okolnímu světu; míru, který je postaven na tisících mrtvých a otrocích trpících pod tíhou kolonialismu. 
politického boje se stala biblická argumentace, samozřejmě zcela vytržená z kontextu. Toto vše pisatelé textů konali s cílem přesvědčit čtenáře, že komunismus a křest́anství jdou ruku v ruce a zároveň ukázat, že bohatý Západ je protikřest’anský, tudíž protikomunistický a amorální.

\section{Zneužití tématu bohatství komunistickým režimem na př́íkladu časopisu Charita}

Abstrakł Studie nejprve ve své metodologické části prìspívá k aktuální teologické diskusi k tématům bohatých, bohatství a pastorace bohatých. Ukazuje základní metodologická omezení, se kterými se badatelé $v$ rámci zkoumání těchto témat mohou setkat. Zejména poukazuje na problematičnost přehledových pojetí $\vee$ kontextu současných odborných diskusí v církevně-historické vědecké obci. Následně se studie zabývá problematikou zneužití tématu bohatství v komunistické propagandě, jejǐz platformou se stal na počátku padesátých let časopis Charita, který vycházel v letech 1946-1951. Přispěvek ukazuje odvrácenou tvář uvažování o bohatých a bohatství: tj. zneužití tohoto tématu k politické propagandě. KSČ totiž vnímala katolickou církev jako svého ideologického nepřitele. Brzy po převzetí moci v Československu v únoru 1948 zakázala většinu katolických novin a časopisů. Ty, co byly nadále vydávány - mezi ně patriil právě časopis Charita - se dostaly pod kontrolu lidí spolupracujících s komunisty. Časopis byl zejména od roku 1949 využiván ke komunistické propagandě, protože v zájmu klidného přebírání a upevňování moci chtěli komunisté získat zejména obyčejné věřící na svoji stranu. Za pomoci kněží, kteři byli dosazeni do redakce, využivala biblickou argumentaci a významné postavy křestanských dějin - včetně Ježišse - v ideologickém boji Východu proti Západu, komunismu proti kapitalismu - a také chudých proti bohatým. Právě tématika bohatství se v roce 1950 stala velmi ostrou zbraní ideologického boje.

Klíčová slova Charita, bohatství, komunismus, církev, propaganda 